\title{
Follicular steroid content and oocyte meiotic status after PMSG stimulation of immature hamsters
}

\author{
P. L. Matson, J. P. P. Tyler* and W. P. Collins \\ Department of Obstetrics and Gynaecology, King's College Hospital Medical School, \\ Denmark Hill, London SE5 8RX, U.K.
}

\begin{abstract}
Summary. Follicular growth was stimulated by the administration of PMSG to immature female hamsters. Changes in the number and size of follicles, their content of progesterone, testosterone, oestradiol, and oestrone (determined in whole follicular homogenates) and the meiotic status of the oocytes, were followed for 4 days to monitor follicular development and ageing. The results showed that $92 \%$ of small antral follicles (371-590 $\mu \mathrm{m}$ ) were seen 24-30 h after PMSG stimulation and that the maximum number of medium- (591-740 $\mu \mathrm{m})$ and large- $(>740 \mu \mathrm{m})$ sized antral follicles occurred $>48 \mathrm{~h}$ later. There was a progressive increase in the concentrations of testosterone, oestradiol and oestrone over the first 48-54 h, but maximal values of oestrone (geometric mean (limits of 1 s.d.): $326.5(230.4-462.7) \mathrm{pg} /$ follicle) lagged $24 \mathrm{~h}$ behind the highest values for testosterone $(352.5(242.0-456.0) \mathrm{pg} /$ follicle $)$ and oestradiol $(718.4(315.7-1634.7) \mathrm{pg} /$ follicle $)$. The progesterone content of all follicles did not change significantly during the first $72-78 \mathrm{~h}$ (range of geometric mean values: $0.25-1.06 \mathrm{ng} /$ follicle), but at $96-102 \mathrm{~h}$ two populations of mediumand large-sized follicles could be distinguished on the basis of a low progesterone concentration (Group 5a: medium, $0.27(0.13-0.55) \mathrm{ng} /$ follicle; large, 0.1 (0.08-0.13 ng/follicle; $P<0.01$ ) or a high concentration (Group 5b: medium, 7.77 $(3 \cdot 12-19 \cdot 36) \mathrm{ng} /$ follicle: large, $13 \cdot 10(8.68-19 \cdot 76 \mathrm{ng} /$ follicle; $P<0.01)$ and this grouping corresponded to the peripheral plasma progesterone values of the animals (Group 5a: $1.32(0.51-3.42) \mathrm{ng} / \mathrm{ml}$; Group 5b: 6.76 (5.05-9.05) ng/ml; $P<0.01)$. Differences in concentrations of testosterone, oestradiol and oestrone were not found in these two groupings at 96-102 h, but large antral follicles at this time contained more oestrone $(\times 1 \cdot 5)$ than medium-sized follicles. Oocytes recovered from follicles up to $78 \mathrm{~h}$ after PMSG stimulation showed few signs of atresia ( $>80 \%$ viable) and had not resumed meiosis ( $>93 \%$ had a visible germinal vesicle). At $96-102$ h oocytes from medium and large follicles with a low progesterone content maintained their viability (>88\%), but $41 \%$ of oocytes recovered from medium-sized follicles showed evidence of germinal vesicle breakdown. However, in follicles containing high concentrations of progesterone the incidence of atresia was high (38-48\%) and most oocytes had resumed meiosis $(>97 \%)$.
\end{abstract}

\section{Introduction}

The relationship between steroid concentrations and the meiotic status of the oocyte in developing and ageing follicles is still incompletely understood. Studies in large domestic animals and women (see review by McNatty, 1978) have shown that the pattern of change in antral fluid

* Present address: Department of Obstetrics and Gynaecology, Parramatta Hospitals/Westmead Centre, Westmead, New South Wales 2145, Australia. 
steroid values throughout follicular development is similar to that seen in peripheral venous plasma, but that concentrations in follicular fluid are greatly elevated. It has been suggested, therefore, that some steroids may play a part in regulating oocyte maturation (Tyler, Smith \& Biggers, 1980). However, the number of oocytes collected from large animals is necessarily limited, or the material is from slaughterhouse animals for which the precise stage of follicular development is unknown.

If small immature laboratory animals are treated with PMSG, follicles are standardized in terms of age and stage of development and larger numbers of oocytes can be collected for study. However, collection of follicular fluid for analysis of steroid content presents many practical problems; for example Goff \& Henderson (1979) were able to aspirate only $4 \mu \mathrm{l}$ fluid from the 2 ovaries of a rat. The aim of the present study was to establish a simple well-defined system using follicular tissue from the hamster to study the relationship between the concentration of steroids and oogenesis in developing and atretic follicles.

\section{Materials and Methods}

\section{Animals}

Thirty-eight (38) immature 25-day-old female golden hamsters (Mesocricetus auratus) were kept in controlled lighting ( $14 \mathrm{~h}$ light $/ 24 \mathrm{~h}$ ) and given water and a pellet diet (Oxoid hamster diet) without restriction. They were each injected intraperitoneally with 40 i.u. PMSG (Sigma Chemical Co., Poole, Dorset, U.K.). Four (4) animals (Group 1) were killed immediately by injection with pentobarbitone sodium (30 mg i.p.; Sagital: May \& Baker Ltd, Dagenham, Essex, U.K.). The other animals, in Groups 2, 3, 4 and 5, were killed 24-30 h after the PMSG $(\mathrm{N}=6)$, at $48-54 \mathrm{~h}(\mathrm{~N}=8), 72-78 \mathrm{~h}(\mathrm{~N}=8)$ and at $96-102 \mathrm{~h}(\mathrm{~N}=11)$ respectively. These times were chosen to include follicular development to a preovulatory state (approx. $60 \mathrm{~h}$ after hCG is usually given to induce superovulation) and a period of follicular ageing before the animals were capable of spontaneously ovulating at approximately $120 \mathrm{~h}$ after PMSG.

The ovaries from individual animals were removed and placed in Eagle's Minimum Essential medium (modified with Earle's salts) containing 20 mM-HEPES (Flow Laboratories Ltd, Irvine, U.K.) and supplemented with BSA (3 mg/ml; Armour Pharmaceutical Co., Eastbourne, U.K.), sodium pyruvate $(0.055 \mathrm{mg} / \mathrm{ml})$, L-glutamine $(0.29 \mathrm{mg} / \mathrm{ml})$ and antibiotics (penicillin, 100 i.u. $/ \mathrm{ml}$; streptomycin, $50 \mu \mathrm{g} / \mathrm{ml}$ ). At the same time blood was obtained by cardiac puncture and the heparinized plasma was frozen at $-20^{\circ} \mathrm{C}$ until assayed for progesterone and LH/PMSG. Representative ovaries from animals in each group were fixed in formal-saline and sectioned at 5 $\mu \mathrm{m}$ for histology.

\section{Follicle dissection}

Individual antral follicles from each pair of ovaries were isolated under a dissecting microscope by using two iris knives and manipulated using an orally-controlled Pasteur pipette. After being classified, on the basis of diameter, into small antral (371-590 $\mu \mathrm{m})$, medium antral $(591-740 \mu \mathrm{m})$ and large antral $(>740 \mu \mathrm{m})$ sizes, batches of about 5 follicles of the same size were collected and transferred to $1 \mathrm{ml}$ culture medium contained in the central well of a $60 \times 15$ mm organ culture dish (Falcon Plastics, from Becton Dickenson, Wembley, London, U.K.). The oocyte from each follicle was released, stripped of cumulus cells by using a finely drawn Pasteur pipette and examined under a dissecting microscope. The observed meiotic status was classified into: those oocytes which had not resumed meiosis and still contained a germinal vesicle (GV); those that had completed the first meiotic division and extruded a polar body (PB); those with neither a germinal vesicle nor a polar body, indicating resumption but not completion of the first 
meiotic division; and those which were abnormal in shape, fragmented, necrotic or cytolysed. The $1 \mathrm{ml}$ culture medium was then subjected to ultrasound to disrupt the cells and frozen at $-20^{\circ} \mathrm{C}$ until assayed for progesterone, testosterone, oestradiol and oestrone.

\section{Radioimmunoassays}

General methods. Steroid was extracted from the given volume of sample by diethyl ether. The dried extract was reconstituted in $100 \mu \mathrm{l}$ buffer $(0.01 \mathrm{M}$-tricine-buffered saline, $\mathrm{pH} 8.0)$ and added to $100 \mu \mathrm{l}$ buffer containing suitably diluted antiserum and $100 \mu \mathrm{l}$ buffer containing tritiated steroid (all purchased from the Radiochemical Centre, Amersham, U.K.). The $300 \mu l$ was thoroughly mixed and allowed to equilibrate overnight at $4^{\circ} \mathrm{C}$. The antibody-bound and free steroid were separated with $0.5 \mathrm{ml}$ dextran-coated charcoal ( $5 \mathrm{~g}$ charcoal and $0.5 \mathrm{~g}$ dextran T70 per litre) and the radioactivity of the supernatant was determined in $4 \mathrm{ml}$ scintillation fluid (Scintillation Cocktail T, Hopkin \& Williams Ltd, Chadwell Heath, Essex, U.K.).

Progesterone. Progesterone was extracted from $50 \mu \mathrm{l}$ samples with $0.5 \mathrm{ml}$ diethyl ether. $\left[{ }^{3} \mathrm{H}\right]$ Progesterone (20000 d.p.m.; sp. act. $101 \mathrm{Ci} / \mathrm{mmol}$ ) and standard solutions of $1,0.5,0.25$, $0.125,0.0625$ and $0.03125 \mathrm{ng} / 100 \mu \mathrm{l}$ were used. The antiserum was raised in a rabbit against progesterone-3-carboxymethyloxime-BSA. The cross-reactions with closely related compounds (i.e. relative amount required to reduce the initial binding of $\left[{ }^{3} \mathrm{H}\right]$ progesterone by $50 \%$ ) were: $5 \alpha$-dihydroprogesterone (14\%), 17-hydroxyprogesterone $(0.5 \%), 20 \alpha$-dihydroprogesterone $(0.5 \%)$, testosterone $(0.2 \%)$ and cortisol $(<0.01 \%)$. The sensitivity was $0.0056 \mathrm{ng} /$ tube, the average recovery $90.7 \%$ and the bias $-9.2 \%$ (over the range of $0.5-10 \mathrm{ng} / \mathrm{ml}$ ). The intra- and inter-assay variation were both $<12 \%$ over 6 months.

Testosterone. Testosterone was extracted from $200 \mu \mathrm{l}$ samples with $1 \mathrm{ml}$ diethyl ether. $\left[{ }^{3} \mathrm{H}\right]$ Testosterone (20000 d.p.m.; sp. act. $\left.83 \mathrm{Ci} / \mathrm{mmol}\right)$ and standard solutions of concentrations $1,0.5,0.25,0.125,0.0625$ and $0.03125 \mathrm{ng} / 100 \mu \mathrm{l}$ were used in the assay. The antiserum was raised in a sheep against testosterone-3-carboxymethyloxime-BSA and cross-reacted with $5 \alpha$-dihydrotestosterone $(14 \%)$, 4-androstene-3,17-dione $(0.8 \%)$, cortisol $(<0.0001 \%)$, $5 \alpha$ androstane-3 $\alpha, 17 \beta$-diol $(6 \%)$ and 5 -androstene-3 $\beta, 17 \beta$-diol $(2 \cdot 1 \%)$. The sensitivity was $5 \cdot 1$ $\mathrm{pg} /$ tube, the average recovery $74 \%$ and the bias $+6.5 \%$ (over the range $0 \cdot 5-10 \mathrm{ng} / \mathrm{ml}$ ). The intra- and inter-assay variations were $<12 \%$ over 6 months.

Oestrone. Oestrone was extracted from $50 \mu \mathrm{l}$ samples with $0.5 \mathrm{ml}$ diethyl ether. Tritiated oestrone (20000 d.p.m.; sp. act. $102 \mathrm{Ci} / \mathrm{mmol}$ ) and standard solutions of concentrations 200 , $100,50,25,12.5$ and $6.25 \mathrm{pg} / 100 \mu \mathrm{l}$ were used. The antiserum was raised in a rabbit against oestrone-6-carboxymethyloxime-BSA and cross-reacted with 2-hydroxyoestrone (0.19\%), $16 \alpha$-hydroxyoestrone $(0.19 \%)$, oestradiol- $17 \beta(<0.01 \%)$, oestriol $(0.01 \%)$ and testosterone $(0.01 \%)$. The sensitivity was $4.1 \mathrm{pg} /$ tube, the average recovery $94 \%$ and the bias $+14.5 \%$ (over the range $300-3000 \mathrm{pg} / \mathrm{ml}$ ). The intra- and inter-assay variations were $<10 \%$ over 6 months.

Oestradiol $-17 \beta$. Oestradiol- $17 \beta$ was extracted from $50 \mu$ samples with $0.5 \mathrm{ml}$ diethyl ether. Tritiated oestradiol-17 $\beta$ (20000 d.p.m.; sp. act. $101 \mathrm{Ci} / \mathrm{mmol}$ ) and standard solutions of concentrations $200,100,50,25,12.5$ and $6.25 \mathrm{pg} / 100 \mu \mathrm{l}$ were used. The antiserum was raised in a rabbit against oestradiol-6-carboxymethyloxime-BSA and cross-reacted with oestrone $(1.7 \%)$, testosterone $(<0.0002 \%)$ and cortisol $(<0.0001 \%)$. The sensitivity of the assay was 3.9 $\mathrm{pg} /$ tube, the average recovery $92 \%$ and the bias $-6.6 \%$ (over the range $300-3000 \mathrm{pg} / \mathrm{ml}$ ). The intra- and inter-assay variations were $<14 \%$ over 6 months.

LH/PMSG. Gonadotrophin concentrations were measured in $100 \mu$ plasma by the double-antibody ovine-ovine LH assay of Niswender, Midgley, Monroe \& Reichert (1968). Values were expressed in terms of the NIH-LH-S18 standard. Since the LH antiserum cross-reacted with PMSG (i.e. 0.02 i.u. PMSG being equivalent to $1.35 \mathrm{ng} / \mathrm{ml} \mathrm{LH}$ ), the assay did not distinguish between LH and PMSG. 


\section{Statistical analysis}

Data on steroid concentrations were initially processed by analyses of variance and when significance was found the difference between groups was compared by Student's $t$ test. Group means and standard deviations were best represented by $\log$ transformations. Because the number of oocytes recovered from each animal was small and the frequency of oocytes in each maturation category even smaller, meaningful $\chi^{2}$ tests for homogeneity of meiotic status could not be done. However, replicate results appeared homogeneous and were, therefore, pooled. The results were expressed in the form of a $2 \times r$ contingency table and the significance of time effects was determined by calculating and partitioning the appropriate $\chi^{2}$ value (Maxwell, 1961). $P$ values $<0.05$ were taken as being statistically significant.

\section{Results}

\section{Peripheral plasma hormones}

The geometric mean ( \pm limits of 1 s.d.) concentrations of plasma progesterone and LH/PMSG for each group are shown in Table 1. Testosterone and the oestrogens could not be assayed because of the small volumes of plasma collected.

Table 1. The concentrations (geometric mean and limits of 1 s.d.) of plasma progesterone and LH/PMSG at various times after stimulation of immature hamsters with PMSG

\begin{tabular}{|c|c|c|c|c|c|c|}
\hline \multirow[b]{3}{*}{ Hormone } & \multicolumn{6}{|c|}{ Time after PMSG (h) } \\
\hline & \multirow{2}{*}{$\begin{array}{c}0 \\
\text { (Group 1) }\end{array}$} & \multirow{2}{*}{$\begin{array}{c}24-30 \\
\text { (Group 2) }\end{array}$} & \multirow{2}{*}{$\begin{array}{c}48-54 \\
\text { (Group 3) }\end{array}$} & \multirow{2}{*}{$\begin{array}{c}72-78 \\
\text { (Group 4) }\end{array}$} & \multicolumn{2}{|c|}{$96-102$} \\
\hline & & & & & Group 5a & Group 5b \\
\hline $\begin{array}{l}\mathrm{LH} / \mathrm{PMSG} \\
(\mathrm{ng} / \mathrm{ml})\end{array}$ & $\begin{array}{c}0.61 \\
(0 \cdot 16-2 \cdot 34)\end{array}$ & $\begin{array}{c}28 \cdot 08 \\
(23 \cdot 44-33 \cdot 63)\end{array}$ & $\begin{array}{c}9 \cdot 40 \\
(4 \cdot 26-20 \cdot 72)\end{array}$ & $\begin{array}{c}3 \cdot 32 \\
(0 \cdot 59-18 \cdot 78)\end{array}$ & $\begin{array}{c}2.96 \\
(1.86-4.69)\end{array}$ & $\begin{array}{c}3 \cdot 53 \\
(2 \cdot 34-5 \cdot 32)\end{array}$ \\
\hline $\begin{array}{l}\text { Progesterone } \\
(\mathrm{ng} / \mathrm{ml})\end{array}$ & $\begin{array}{c}2 \cdot 42 \\
(1 \cdot 54-3 \cdot 80)\end{array}$ & $\begin{array}{c}8 \cdot 81 \\
(7 \cdot 40-10 \cdot 49)\end{array}$ & $\begin{array}{c}2 \cdot 27 \\
(1 \cdot 25-4 \cdot 15)\end{array}$ & $\begin{array}{c}1 \cdot 38 \\
(0.47-4 \cdot 06)\end{array}$ & $\begin{array}{c}1.32 \\
(0.51-3.42)\end{array}$ & $\begin{array}{c}6 \cdot 76 \\
(5 \cdot 05-9 \cdot 05)\end{array}$ \\
\hline
\end{tabular}

Progesterone. By $24 \mathrm{~h}$ after PMSG injection the mean concentration had increased 4-fold $(P<0.01)$, but then decreased progressively. In Group 5, however, 4 animals had low plasma progesterone values similar to those in Group 4, whilst the others had elevated values $(P<0.01)$. These animals were therefore distinguished as Groups $5 \mathrm{a}$ and $5 \mathrm{~b}$ respectively.

$L H / P M S G$. The concentration of LH/PMSG (Table 1) was also greatest in Group 2 animals but was nearly basal in Group 5 . There were no differences between Groups $5 \mathrm{a}$ and $5 \mathrm{~b}$ for this hormone.

\section{Follicle size distribution}

The frequency with which the 630 antral follicles of defined size were obtained at dissection is shown in Table 2. There were no antral follicles $>370 \mu \mathrm{m}$ in Group 1. Most follicles in Group 2 were small but approximately equal numbers of small and medium-sized follicles were found in Group 3. No large follicles were seen at this time. The number of small follicles that could be isolated then decreased, with none being found in Group 5. The maximum number of large-sized antral follicles occurred in Group 4 although the majority of follicles in this group were of medium size. There was a clear difference in distribution of follicles within Groups 5a and 5b, with twice as many medium-sized follicles in Group 5a than in Group 5b and the reverse pattern for large follicles. 
Table 2. The mean number of antral follicles of different size dissected per ovary from immature hamsters after stimulation with PMSG

\begin{tabular}{lcccccc}
\hline & \multicolumn{5}{c}{ Time after PMSG (h) } \\
\cline { 2 - 6 } $\begin{array}{c}\text { Follicle } \\
\text { size }(\mu \mathrm{m})\end{array}$ & $\begin{array}{c}0 \\
\text { (Group 1) }\end{array}$ & $\begin{array}{c}24-30 \\
(\text { Group 2) }\end{array}$ & $\begin{array}{c}48-54 \\
(\text { Group 3) }\end{array}$ & $\begin{array}{c}72-78 \\
\text { (Group 4) }\end{array}$ & Group 5a & Group 5b \\
\hline $\begin{array}{c}\text { Small } \\
(371-590)\end{array}$ & 0.0 & $3.8(92)$ & $3.1(50)$ & $1.6(9.4)$ & $0.0(0)$ & $0.0(0)$ \\
$\begin{array}{c}\text { Medium } \\
(591-740)\end{array}$ & 0.0 & $0.2(4)$ & $3.1(50)$ & $10.8(62.8)$ & $10.1(84.2)$ & $4.4(59.5)$ \\
$\begin{array}{c}\text { Large } \\
(>740)\end{array}$ & 0.0 & $0.2(4)$ & $0.0(0)$ & $4.9(28.3)$ & $1.9(15.8)$ & $3.0(40.5)$ \\
\hline
\end{tabular}

Values in parentheses are $\%$ of the total number of follicles dissected for that time period.

\section{Follicular steroid content}

The values for mean content of progesterone, testosterone, oestradiol and oestrone are shown in Table 3.

Progesterone. In small antral follicles the values in Groups 3 and 4 did not differ significantly, although the values in both groups were significantly lower $(P<0.005)$ than that in Group 2 . In medium- and large-sized antral follicles there were no differences in Groups 3 and 4, but values in Groups $5 \mathrm{a}$ and $5 \mathrm{~b}$ were clearly distinguishable and related to the peripheral plasma progesterone status of each animal. The follicular content of progesterone in Group 5a was not significantly different from that in Groups 3 and 4, but the value in Group 5b was significantly greater $(P<0.001)$ than that for Group 5a. A similar, but greater, difference $(P<0.001)$ was seen for the large follicles in Groups $5 \mathrm{a}$ and $5 \mathrm{~b}$.

Testosterone. In small antral follicles the mean values in Groups 3 and 4 were similar although both were significantly higher than that in Group 2. The highest concentration of testosterone was found in medium-sized antral follicles in Group 3, with values in medium- and large-sized follicles in Groups 4 and 5 being much lower $(P<0.05)$. There was no difference between Groups $5 \mathrm{a}$ and $5 \mathrm{~b}$.

Oestradiol-17 $\beta$. In small follicles the mean concentrations in Groups 3 and 4 were similar and significantly lower than that in Group 2. The pattern was reversed in medium-sized follicles. In medium- and large-sized antral follicles oestradiol values were decreased in Group 5, but Groups $5 \mathrm{a}$ and $5 \mathrm{~b}$ could be distinguished by the mean concentrations in the medium-sized follicles.

Oestrone. The pattern of oestrone changes was not the same as that for oestradiol; the highest values were found in medium and large follicles in Group 4. In medium-sized follicles values were significantly different in Groups 2 and 3 while in small follicles concentrations were similar in Groups 2 and 3 but significantly increased in Group 4. Values in Groups 5a and 5b were similar and significantly lower than in Group 4. Large follicles contained approximately 1.5 times more oestrone than did medium-sized follicles.

\section{Meiotic status of oocytes}

The meiotic status of oocytes recovered from antral follicles at different times after PMSG is shown in Table 4. In oocytes from small follicles, there was a progressive and significant increase in viability from $80 \%$ in Group 2 to $91 \%$ in Group $3(P<0.05)$ and $97 \%$ in Group $4(P<0.01)$. Within medium-sized follicles, the viability of the oocytes recovered in Group $3(94 \%)$ and Group $4(95 \%)$ was not significantly different. However, viability of Group 5 oocytes was 
P. L. Matson et al.

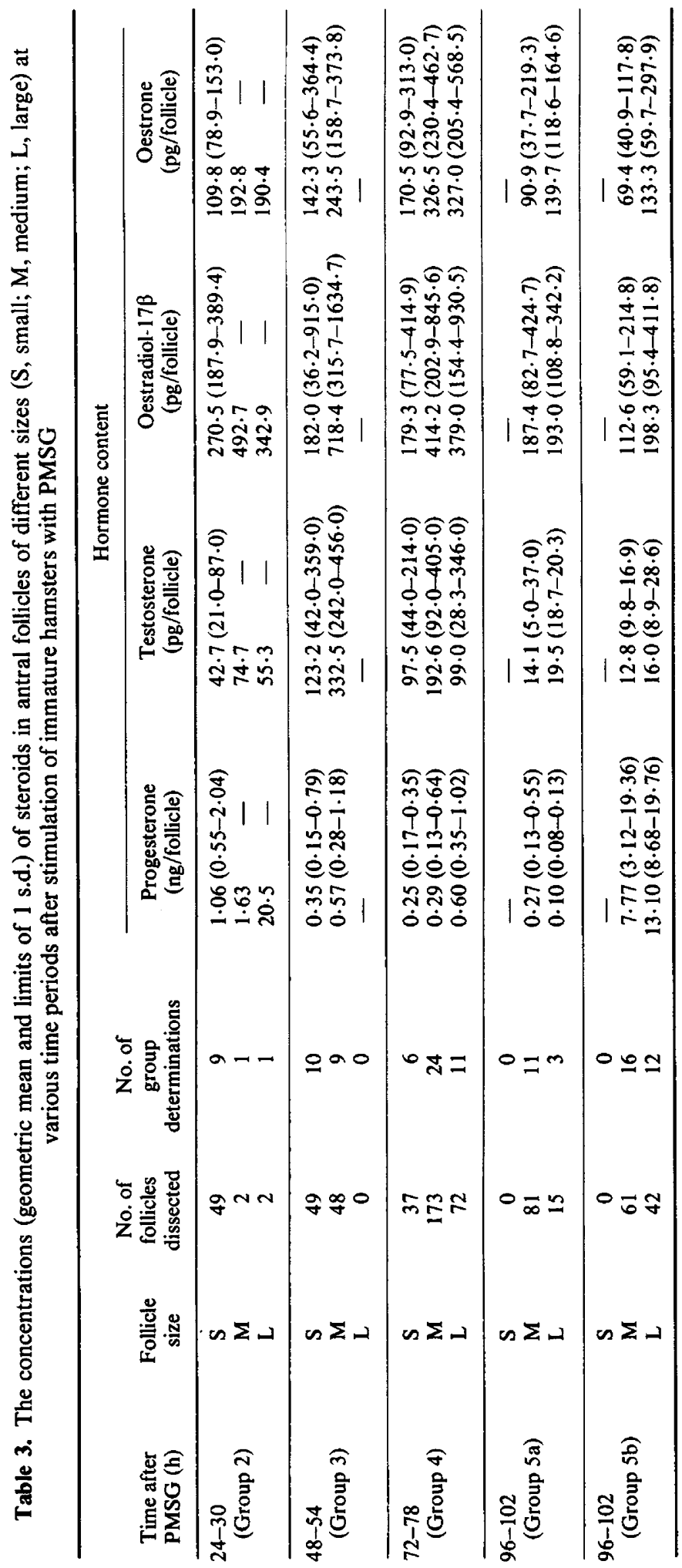


significantly lower than that of Group 4 oocytes, the fall being more marked in Group 5b (52\%: $P<0.001)$ than in Group 5a $(88 \%: P<0.05)$. The viability of oocytes from large follicles in Group 5a (94\%) was not significantly different from that in Group 4, but viability of Group $5 \mathrm{~b}$ oocytes was lower (62\%: $P<0.01$ ) than that for Group 4.

The incidence of germinal vesicle breakdown (GVBD) in small and medium-sized follicles in Groups 2,3 and 4 was consistently low ( $<6 \%$ ). GVBD occurred with a greater frequency in oocytes from medium-sized follicles in Groups 5a $(41 \%: P<0.001)$ and 5 b $(92 \%: P<0.001)$, but the incidence of GVBD in these two groups differed significantly $(P<0.001)$. All viable oocytes recovered from large follicles in Group 5a had retained a germinal vesicle whilst all those from Group 5b had undergone GVBD.

Table 4. The meiotic status of oocytes recovered from antral follicles of different sizes (S, small; M, medium; L, large) after stimulation of immature hamsters with PMSG

\begin{tabular}{|c|c|c|c|c|c|}
\hline \multirow{2}{*}{$\begin{array}{l}\text { Time after } \\
\text { PMSG (h) }\end{array}$} & \multirow{2}{*}{$\begin{array}{l}\text { Follicle } \\
\text { size }\end{array}$} & \multirow{2}{*}{$\begin{array}{l}\text { Total } \\
\text { no. of } \\
\text { oocytes }\end{array}$} & \multicolumn{3}{|c|}{ Stage of meiosis } \\
\hline & & & GV & GVBD $(\%)^{*}$ & Degenerating $(\%) \dagger$ \\
\hline $\begin{array}{l}\text { 24-30 } \\
\text { (Group 2) }\end{array}$ & $\begin{array}{l}\mathrm{S} \\
\mathrm{M} \\
\mathrm{L}\end{array}$ & $\begin{array}{r}45 \\
2 \\
2\end{array}$ & $\begin{array}{r}36 \\
1 \\
0\end{array}$ & $\begin{array}{l}0(0) \\
0(0) \\
2(100)\end{array}$ & $\begin{array}{l}9(20) \\
1(50) \\
0(0)\end{array}$ \\
\hline $\begin{array}{l}\text { 48-54 } \\
\text { (Group 3) }\end{array}$ & $\begin{array}{l}\mathrm{S} \\
\mathrm{M} \\
\mathrm{L}\end{array}$ & $\begin{array}{r}49 \\
48 \\
-\end{array}$ & $\begin{array}{r}44 \\
44 \\
-\end{array}$ & $\begin{array}{l}1(2) \\
1(2) \\
-\end{array}$ & $\begin{array}{l}4(9) \\
3(6) \\
-\end{array}$ \\
\hline $\begin{array}{l}\text { 72-78 } \\
\text { (Group 4) }\end{array}$ & $\begin{array}{l}\mathrm{S} \\
\mathrm{M} \\
\mathrm{L}\end{array}$ & $\begin{array}{r}37 \\
173 \\
72\end{array}$ & $\begin{array}{r}34 \\
159 \\
62\end{array}$ & $\begin{array}{l}2(6) \\
5(3) \\
5(7)\end{array}$ & $\begin{array}{l}1(3) \\
9(5) \\
5(7)\end{array}$ \\
\hline $\begin{array}{l}96-102 \\
\text { (Group 5a) }\end{array}$ & $\begin{array}{l}S \\
M \\
L\end{array}$ & $\begin{array}{l}\overline{81} \\
15\end{array}$ & $\begin{array}{l}\overline{42} \\
14\end{array}$ & $\begin{array}{c}\overline{29}(41) \\
0(0)\end{array}$ & $\begin{array}{c}\overline{10}(12) \\
1(6)\end{array}$ \\
\hline $\begin{array}{l}96-102 \\
\text { (Group 5b) }\end{array}$ & $\begin{array}{l}\text { S } \\
M \\
L\end{array}$ & $\begin{array}{l}-\overline{61} \\
42\end{array}$ & $\begin{array}{r}- \\
1 \\
0\end{array}$ & $\begin{array}{l}\overline{31}(97) \\
26(100)\end{array}$ & $\begin{array}{l}\overline{29}(48) \\
16(38)\end{array}$ \\
\hline
\end{tabular}

$\mathrm{GV}=$ germinal vesicle; GVBD = germinal vesicle breakdown.

* Of oocytes which were not abnormal or necrotic (degenerating).

$\uparrow$ Of total oocytes recovered.

\section{Follicular steroids and meiotic status of oocytes}

When the numbers of atretic oocytes or those with GVBD (Table 4) were compared with follicular concentrations of the four steroids measured (Table 3) there was no relationship between the meiotic status of the oocyte and follicular size, or steroid concentration up to $78 \mathrm{~h}$ after PMSG stimulation.

When the data from medium- and large-sized antral follicles in Groups 5a and 5b were considered, in all follicles with high progesterone content (Group 5b) the incidence of atretic oocytes (overall 44\%) was significantly greater than in follicles with low progesterone concentrations (Group 5a, overall 12\%: $P<0.05$ ). The pattern is similar for GVBD, with $99 \%$ of oocytes resuming meiosis in Group 5a. The oocytes resuming meiosis from the Group $5 \mathrm{~b}$ follicles showed a greater incidence of polar body formation (65\%) than did those from Group 5 a (3\%).

\section{Discussion}

A method has been evaluated in which the steroid content of homogenized whole follicles can be determined after assessment of the meiotic status of the contained oocyte. The administration of 
PMSG to prepubertal 25-day-old hamsters results in follicular development without ovulation during the first 4 days (as indexed by the absence of corpora lutea in the excised ovaries and the presence of an oocyte in each dissected follicle), and therefore steroid levels and the subsequent progress of oocytes in developing and ageing follicles can be monitored. Furthermore, the use of PMSG in immature animals gives rise to stimulated follicles which are standardized with respect to age and stage of development, an important point since it has been suggested that one role of FSH in the cyclic hamster is the stimulation of follicles for the following oestrous cycle, thereby introducing more than one generation of follicles into the ovary (Sheela Rani \& Moudgal, 1977; Chappel \& Selker, 1979).

After the injection of PMSG the size and distribution of follicles within the ovary changed. The majority (92\%) of small antral follicles were dissected 24-30 h after injection and their numbers then decreased as larger sizes appeared. That no small antral follicles were present 96-102 h after PMSG probably indicates that there is no new recruitment of follicles after about $48 \mathrm{~h}$. The sizes of the follicles dissected corresponded well with those reported by Iwamatsu \& Yanagamachi (1975) in adult cyclic hamsters. After 48-54 h equal numbers of small and medium-sized follicles were seen, and follicular proliferation, gauged by the increase in the number of follicles obtained per ovary, had begun. The greatest number of medium-sized follicles occurred during the $72-78 \mathrm{~h}$ period, $24 \mathrm{~h}$ after the time when hCG is usually given to PMSG-primed immature hamsters for the induction of ovulation (Bodemer, Rumery \& Blandau, 1959). Before this time few large preovulatory follicles were present. The proliferation of follicles observed after $48-54 \mathrm{~h}$ is coincident with the decrease of plasma progesterone concentrations, thereby being consistent with the idea that progesterone is associated with the inhibition of follicular growth (Buffler \& Roser, 1974; Moore \& Greenwald, 1974). This pattern of plasma progesterone is parallel and similar in value to that seen in the cyclic adult hamster during the luteal-follicular phase shift of the oestrous cycle (Saidapur \& Greenwald, 1978; Terranova \& Greenwald, 1978). That plasma progesterone concentrations were elevated 24-30 h after PMSG without the concomitant increase in follicular values suggests that the source of this steroid was either the interstitium or extra-ovarian (i.e. adrenal).

No endogenous surge of LH ( $>1000 \mathrm{ng} / \mathrm{ml}$; Bex \& Goldman, 1974) was detected throughout the period of study, but the levels of circulating gonadotrophins were elevated in comparison to the basal value, probably reflecting the long biological half-life of PMSG (Sasamoto, Sato \& Naito, 1972) and its cross-reaction with the LH antiserum.

The changing size distribution of antral follicles with time also corresponds well with the accepted pattern of changes in follicular steroid concentrations found in larger species (McNatty, 1978). There is a progressive increase in the concentration of testosterone, oestradiol and oestrone related to growth of the antral follicle. Maximal concentrations of testosterone and oestradiol occur in medium-sized follicles at the periovulatory period (if hCG were to be given) 48-54 h after PMSG. Maximal values for oestrone were also greatest in medium-sized follicles, but lagged behind those of oestradiol by $24 \mathrm{~h}$, reflecting its position in the biochemical pathway. Follicular testosterone concentrations were lowest in the oldest follicles which readily convert androgens to oestrogens (Kemeter, Salzer, Breitenecker \& Friedrich, 1975). This pattern of follicular hormonal changes mimics that for steroids in whole ovaries of adult cyclic hamsters in which concentrations increase over Days 1-3 and then decline on the day of ovulation (Saidapur \& Greenwald, 1978).

The changes in follicular content of progesterone differ from those of the other steroids in that values initially decrease and then remain relatively unchanged with time until 96-102 $\mathrm{h}$ when some follicles contained a massive increase in progesterone content (Group 5b). This concentration was similar to values measured in preovulatory follicles of adult animals (Norman \& Greenwald, 1971). Vermeiden \& Zeilmaker (1974) have shown that in rats lower amounts of gonadotrophins are required to bring about oocyte maturation and luteinization than are needed for follicular rupture, and the increase in progesterone production and GVBD in oocytes in 
Group $5 \mathrm{~b}$ follicles may be explained in this way. However, the histological data revealed no morphological evidence of luteinization in Group 5b follicles compared to follicles at the other times, so one can only conclude that these cells had undergone biochemical changes without the morphological changes obvious under the light microscope. That some animals at this time period responded to the gonadotrophins whilst others did not probably reflects differences in the stage of follicular development, despite the animals being the same age, because no significant differences were found in LH/PMSG values after 96-102 h. The increase in follicular volume may also have diluted the effects of oocyte maturation inhibitor and granulosa cell luteinization inhibitors demonstrated to exist in follicular fluid (Tsafriri, 1978). In follicles with high progesterone concentrations (Group 5b) GVBD was almost total (97-100\%) and the incidence of oocyte atresia was high ( 48 and $38 \%$ ).

The meiotic status of follicle-enclosed oocytes was not affected by the changing pattern of hormones up until $78 \mathrm{~h}$ after PMSG and most oocytes retained a germinal vesicle. The fact that almost $20 \%$ of recovered oocytes were necrotic at $24-30 \mathrm{~h}$, but generally $<10 \%$ thereafter, may reflect the ability of gonadotrophins to rescue the follicles from atresia (Peters, Byskov, Himelstein-Braw \& Faber, 1975), although this premise has been questioned (Dott, Hay, Cran \& Moor, 1979). The major change in meiotic scores occurred at 96-102 $\mathrm{h}$ after PMSG when two distinct populations of oocytes could be identified on the basis of the peripheral plasma progesterone values. This difference could not be explained by follicles being out of phase with each other with respect to time, since the animals were injected with PMSG at the same age and two follicle types could be distinguished within both medium and large follicles in this group.

The results of these experiments have demonstrated that the pattern of steroid changes during folliculogenesis in the PMSG-stimulated immature hamster appears to mirror the changes occurring during the oestrous cycle of the adult animal. Furthermore, in ageing follicles high concentrations of progesterone are associated with a high incidence of oocyte atresia and germinal vesicle breakdown.

We are grateful to Dr B. Gledhill for analysing the samples of LH/PMSG.

\section{References}

Bex, F.J. \& Goldman, B.D. (1974) Serum gonadotrophins and follicular development in the Syrian hamster. Endocrinology 96, 928-933.

Bodemer, C., Rumery, R.E. \& Blandau, R.J. (1959) Studies on induced ovulation in the intact immature hamster. Fert. Steril. 10, 350-360.

Buffier, G. \& Roser, S. (1974) New data concerning the role played by progesterone in the control of follicular growth in the rat. Acta endocr., Copenh. 75, 569-578.

Chappel, S.C. \& Selker, F. (1979) Relation between the secretion of FSH during the periovulatory period and ovulation during the next cycle. Biol. Reprod. 21, $347-352$.

Dott, H.M., Hay, M.F., Cran, D.G. \& Moor, R.M. (1979) Effect of exogenous gonadotrophins (PMSG) on the antral follicle population in the sheep. $J$. Reprod. Fert. 56, 683-689.

Goff, A.K. \& Henderson, K.M. (1979) Changes in the follicular fluid and serum concentrations of steroids in PMS treated immature rats following $\mathrm{LH}$ administration. Biol. Reprod. 20, 1153-1157.

Iwamatsu, T. \& Yanagamachi, R. (1975) Maturation in vitro of ovarian oocytes of prepubertal and adult hamsters. J. Reprod. Fert. 45, 83-90.
Kemeter, P., Salzer, H., Breitenecker, G. \& Friedrich, F. (1975) Progesterone, oestradiol- $17 \beta$ and testosterone levels in the follicular fluid of tertiary follicles and Graafian follicles of human ovaries. Acta endocr., Copenh. 80, 686-704.

Maxwell, A.E. (1961) Analysing Qualitative Data, pp. 11-62. Methuen, London.

McNatty, K.P. (1978) Follicular fluid. In The Vertebrate Ovary: Comparative Biology and Evolution, Ch. 7, pp. 215-259. Ed. R. E. Jones. Plenum, New York.

Moore, P.J. \& Greenwald, G.S. (1974) Effect of hypophysectomy and gonadotrophin treatment on follicular development and ovulation in the hamster. Am. J. Anat. 139, 37-48.

Niswender, G.D., Midgley, A.R., Jr, Monroe, S.E. \& Reichert, L.H., Jr (1968) Radioimmunoassay for rat luteinizing hormone with antiovine LH serum and ovine LH ${ }^{131}$ I. Proc. Soc. exp. Biol. Med. 128, $807-811$.

Norman, R.L. \& Greenwald, G.S. (1971) Effect of Phenobarbital, hypophysectomy and $\mathbf{x}$-irradiation on preovulatory progesterone levels in the cyclic hamster. Endocrinology 89, 598-605.

Peters, H., Byskov, A.G., Himelstein-Braw, R. \& Faber, M. (1975) Follicular growth: the basic event in 
mouse and human ovary. J. Reprod. Fert. 45, $559-566$.

Saidapur, S.K. \& Greenwald, G.S. (1978) Peripheral blood and ovarian levels of sex steroids in the cyclic hamster. Biol. Reprod. 18, 401-408.

Sasamoto, S., Sato, K. \& Naito, H. (1972) Biological active life of PMSG in mice with special reference to follicular ability to ovulate. J. Reprod. Fert. 30, 371-379.

Sheela Rani, C.S. \& Moudgal, N.R. (1977) Role of the proestrous surge of gonadotrophins in the initiation of follicular maturation in the cyclic hamster: a study using antisera to FSH and LH. Endocrinology 101, 1484-1494.

Terranova, P.F. \& Greenwald, G.S. (1978) Steroid and gonadotrophin levels during the luteal-follicular shift of the cyclic hamster. Biol. Reprod. 18, 170-175.

Tsafriri, A. (1978) Oocyte maturation in mammals. In The Vertebrate Ovary: Comparative Biology and Evolution, Ch. 11, pp. 409-433. Ed. R. E. Jones. Plenum, New York.

Tyler, J.P.P., Smith, D.M. \& Biggers, J.D. (1980) Effect of steroids on oocyte maturation and atresia in mouse ovarian fragments in vitro. J. Reprod. Fert. 58, 203-212.

Vermeiden, J.P.W. \& Zeilmaker, G.H. (1974) Relationship between maturation division, ovulation and luteinization in the female rat. Endocrinology 95, 341-351. 